\title{
Nilai Pendidikan Karakter Dalam Cerita Rakyat Nias dan Potensinya Sebagai Materi Pembelajaran Sastra di SMA
}

\author{
Esra Parida Siregar ${ }^{1}$, Ivoni Evi Marwati Ndururu ${ }^{2}$, Sadieli Telaumbanua ${ }^{3}$ \\ E-mail : esrasiregar84@gmail.com ${ }^{1}$, ivonievi15@gmail.com² ${ }^{2}$ kadisgusit@gmail.com \\ Universitas Prima Indonesia
}

\begin{abstract}
Abstrak
Penelitian ini bertutujuan untuk mendeskripsikan nilai-nilai pendidikan karakter yang terdapat dalam cerita rakyat Nias dan mendeskripsikan potensi cerita rakyat Nias sebagai pembelajaran sastra di SMA. Pendekatan yang di lakukan dalam penelitiani adalah pendekatan Kualitatif. Penelitian ini menggunakan metode analisis isi atau content analysis. Sumber datanya ialah buku cerita rakyat Nias.Teknik pengumpulan data dialakukan dengan pengamatan atau pemeriksaan teks (naskah) atau pembacaan.Landasan analisis data ialah analisis neurostik dan analisis antropologi Linguistik. Berdasarkan hasil penelitian ditemukan bahwa nilai-nilai pendidikan karakter yang terdapat dalam cerita rakyat Nias ialah nilai religius, kepribadian baik, kepedulian sosial, kejujuran dan kerja keras. Cerita rakyat Nias berpotensi kuat untuk dijadikan sebagai pembelajaran sastra di SMA karena memiliki dimensi kognitif, afektif, dan psikomotor. Cerita rakyat Nias mampu menumbuhkan sikap yang lebih santun dan beradab bagi hidup siswa-siswi SMA serta cerita rakyat Nias dapat dijadikan sumber pembentukan karakter yang berdaya saing dalam diri siswa-siswi SMA.Oleh sebab itu, sastra-sastra yang bersifat lokal agar dapat dijadikan sebagai materi pembelajaran sastra di SMA mengingat nilai-nilai pendidikan karakter yang terkandung di dalamnya dan demi membentuk karakter-karakter siswa menjadi manusia sejati.
\end{abstract}

Kata Kunci: Pendidikan Karakter, Cerita Rakyat Nias, Pembelajaran Sastra SMA

\section{PENDAHULUAN}

Pendidikan tidak asing lagi di tengah-tengah masyarakat sekarang ini. Dikarenakan kegiatan pendidikan yang tidak dapat dipisahkan dengan kehidupan seharihari, bahkan di seluruh lapisan kehidupan manusia. Dengan kata lain, bahwa pendidikan sama pentingnya dengan kebutuhan lain, seperti sandang (pakaian), pangan (makanan), dan papan (perumahan). Menurut Bahasa, karakter berasal dari Bahasa inggris, Character yang berarti watak,sifat, dan karakter (Echols dan Shadily, 2015 : 107). Dalam Bahasa Indonesia watak diartikan sebagai sifat batin manusia yang memengaruhi 
sengenap pikiran dan perbuatannya ; dan berarti pul tabi'at serta budi pekerti dengan demikian, pendidikan katrakter adalah upaya memengaruhi segenap pikiran dan sifat batin peserta didik dalam rangka membentuk watak, budi pekerti, dan kepribadiannya (Purwadarninta, 2013 : 1149).

Pendidikan karakter dan sastra saling berkaitan, sastra yang dimaksud dalam hal ini tidak hanya sebatas pada sastra yang sifatnya modern, namun juga sastra yang bersifat kedaerahan (lokal) atau sastra daerah.Salah satunya adalah sastra lisan berupa cerita rakyat.Cerita rakyat Suku Nias termasuk salah satu jenis karya sastra daerah, sekaligus merupakan kebudayaan nusantara yang masih dianut, tumbuh, dan berkembang di tengah-tengah masyarakatnya.Cerita rakyat Suku Nias adalah genre sastra lisan yang disampaikan dan diwariskan secara turun-temurun dari generasi ke generasi. Terkait dengan pembinaan dan pengembangan sastra daerah dalam Peraturan Pemerintah RI No. 57 Tahun 2014 tentang Pengembangan,Pembinaan,dan Perlindungan Bahasa dan Sastra, serta Peningkatan Fungsi Bahasa Indonesia Pasal 24 ayat 2 dinyatakan bahwa pembinaan Sastra Daerah dilakukan melalui: (1) pendidikan sastra; (2) pelatihan sastra; (3) penyediaan fasilitas untuk mendorong berkembangnya komunitas sastra; (4) penyediaan fasilitas untuk menyajikan karya sastra; dan (5) penciptaan suasana yang kondusif untuk bersastra.Dilihat dari Peraturan Pemerintah RI No. 57 Tahun 2014 di atas, salah satu wujud pembinaan dan pengembangan sastra lisan,khususnya cerita rakyat masyarakat Suku Nias menjadikannya sebagai Bahan ajar dalam pembelajaran sastra di sekolah Menengah Atas. Untuk itu haruslah diperhatikan nilai pendidikan karakter apa sajakah yang terkandung dalam cerita dan apakah cerita rakyat tersebut relevan atau tidak sebagai materi pembelajaran sastra? Khususnya dalam pembelajaran sastra di sekolah Menengah Atas.

Kajian tentang nilai pendidikan karakter yang terkandung dalam cerita dan relevansinya sebagai materi pembelajaran sastra di sekolah dasar perlu dilakukan karena merupakan salah satu langkah untuk membentuk karakter siswa sekaligus sebagai perwujudan kecintaan dan pembinaan terhadap kebudayaaan asli nusantara. Dalam yang akan dipaparkan adalah cerita rakyat asli milik masyarakat Suku Nias. Agung (2011:394) mengatakan ada tiga fokus pendidikan karakter,yaitu berfokus pada nilainilai ajaran, nilai klarifikasi, dan pengembangan moral. Sejalan dengan tiga fokus 
pendidikan karakter tersebut, Sugirin (2011:1) menyatakan bahwa pendidikan karakter merupakan sesuatu yang sangat penting dengan tujuan untuk menerapkan nilai-nilai kebaikan dalam kehidupan sehari-hari.Pendidikan yang dimaksud dalam hal ini adalah pendidikan nilai, pendidikan budi pekerti, pendidikan moral, dan pendidikan watak.

Nilai Pendidikan Karakter Cerita Rakyat Suku Nias bertujuan pada pembentukan karakter dan menjadi wujud nilai-nilai budi pekerti luhur. Terkait dengan sastra, secara umum dikenal ada dua jenis sastra, yaitu sastra lisan dan sastra tulis. Sastra lisan sering dikenal dengan istilah folklore atau cerita rakyat yang telah mentradisi hidup dan dipertahankan oleh masyarakat pemiliknya (Nur-giyantoro, 2013 :10). Dengan demikian, dapat dikatakan bahwa cerita rakyat salah satu bagian dari folklor.Barone (2011:60) mengemukakan bahwa cerita rakyat merupakan bagian dari sastra tradisional. Berdasarkan penjelasan di atas, dapat disimpulkan bahwa cerita rakyat merupakan salah satu bentuk sastra lisan dari zaman dahulu yang diwariskan secara turun-temurun dari generasi ke generasi, berkembang di kalangan rakyat, tidak diketahui nama pengarangnya. Kemudian, cerita rak-yat juga dianggap sebagai kepercayaan yang telah mentradisi dalam masyarakat, dipertahankan oleh masyarakat pemiliknya, dan merupakan salah satu bagian dari folklor.Kaitannya dengan pendidikan karakter, Wibowo (2013:131) mengemukakan empat ni-lai dalam suatu karya sastra yang baik sebagai materi pembelajaran sastra. Empat nilai tersebut, yaitu nilai estetis, nilai humanis, nilai etis, dan nilai religius.

Tujuan Penelitian ialah untuk mengetahui cerita rakyat Nias yang berpotensi sebagai materi pembelajaran Sastra di SMA dan Untuk mendeskripsikan nilai-nilai pendidikan karakter yang terdapat dalam cerita rakyat Nias. Berdasarkan uraian di atas peneliti melakukan penelitian tentang Nilai Pendidikan Karakter dan Potensinya Sebagai Materi Pembelajaran di SMA.

\section{METODE PENELITIAN}

Penelitian tentang Nilai Pendidikan Karakter dan Potensinya Sebagai Materi Pembelajaran di SMA dilaksanakan pada tahun 2020 mulai November 2019 sampai dengan November 2020. Pendekatan yang di lakukan dalam penelitian ini adalah

pendekatan Kualitatif.Arikunto (2009:195) menyebutkan bahwa penelitian kualitatif 
merupakan penelitian deskriptif karena penelitian ini berusaha menggambarkan data dengan kata-kata atau kalimat yang dipisahkan menurut kategori untuk memperoleh simpulan. Penelitian yang mengharuskan peneliti mengkaji fenomena yang terjadi secara alamiah dengan segala kompleksitasnya Fraenkel dan Wallen (2007) Penelitian ini menggunakan metode analisis isi atau content analysis( Fraenkel dan Wallen: 2007:483) yakni teknik yang dapat digunakan peneliti untuk mengkaji perilaku manusia secara tidak langsung melalui analisis terhadap komunikasi mereka seperti buku teks, esay, koran, novel, artikel majalah, lagu, gambar iklan dan semua jenis komunikasi yang dapat dianalisis.Sumber data penelitian ini adalah berupa Teks.Sumber datanya ialah Buku tentang cerita rakyat Nias. Teknik pengumpulan data dengan pengamatan atau pemeriksaan teks ( naskah) atau pembacaan. Teknik analisis Data menggunakan analisis Neurostik dan analisis antropologi Linguistik.

\section{HASIL PENELITIAN DAN PEMBAHASAN}

Pelaksanaan pembelajaran pendidikan karakter menurut Lickona Thomas (1992 : 54) yaitu" mempunyai dasar kurikulum yang mengandung nilai-nilai karakter dan terintegrasi dalam mata pelajaran yang diajarkan kepada peserta didik nantinya". Menurut Thomas Lickona (1992) dalam Masmur Muslich ( 2011: 29) Pendidikan karakter adalah susatu sistem penanaman nilai-nilai karakter kepada warga sekolah yang meliputi komponen pengetahuan, kesadaran atau kemauan dan tindakan untuk melaksanakan nilai-nilai tersebut, baik terhdap Tuhan Yang Maha Esa, diri sendiri, sesama, lingkungan, maupun kebangsaan sehingga menjadi manusia insan Kamil. Nilainilai pendidikan karakter yang terdapat dalam cerita rakyat Nias berdasarkan hasil penelitian ialah

\section{Nilai Religius}

Untuk membentuk karakter religius maka ada tiga pihak yang harrus mendukung terbentuknya karakter religius tersebut. Yang pertama itu keluarga, kedua sekolah dan lingkungan. Pertama, pihak keluarga karena pendidikan yang pertama dimana anak mendapatkan pengetahuan dan pemahaman tentang agama dari orang tua, sehinggga pendidikan yang paling banyak di terima oleh anak adalah dalam keluarga.Dapat dipahami bahwa orang tua memengang faktor kunci yang dapat 
menjadikan anak tumbuh dengan nilai keagaaman. Hal ini sangat bergantung pada pembentukan karakter religius, serta peranan orang tua sebagai pembuka mata uang pertama bagi anak dalam rumah tangga (Jamaluddin, 2013: 37).

Nilai Religius menurut Shihab (1993) adalah hubungan antara makhluk dengan khalik (Tuhan) yang berwujud dalam ibadah yang dilakukan dalam sikap keseharian (Ghufrom dan Risnawita, 2010). Berbeda pula dengan pendapat Glock dan Strack (dalam Nashori dan Mucharam dalam Solahuddin), menyatakan bahwa religius adalah sistem simbol, keyakinan, sistem nilai dan sistem perilaku yang terlembagakan, yang semuanya berpusat pada persoalan-persoalan yang dihayati sebagai sesuatu yang maknawi (Palupi, 2013). Sehingga dapat ditarik sebuah kesimpulan bahwa nilai karakter religius adalah nilai sikap dan perilaku yang patuh dalam ajaran agama yang di anutnya, toleran terhadap pelaksaan ibadah agama lain, hidup rukun dengan agama lain. Maka sebagai peserta didik diharapkan untuk selalu mengedepankan karakter nilai religius.

Nilai religius pada buku cerita rakyat Nias terdapat pada judul "MOLO MANAHO”, berikut penggalannya (hal : 37 paragraf ke dua) “Ama Wangehao sangat bersyukur pada Tuhan memiliki anak yang berperangai baik, mematuhi nasihat orang tua serta rajin beribadah kepada Tuhan. Ibu mereka (Ina Wangehao ) selalu mengigatkan ketiga anaknya akan firman Tuhan : a) Takut akan Tuhan adalah permulaan pengetahuan, b) Hai anakku, dengarlah didikan ayahmu dan jangan menyianyiakan ajaran ibumu, c) Hai anakku, janganlah engkau menolak didikan Tuhan dan jangan engkau bosan akan peringatan-Nya, karena Tuhan memberi ajaran kepada yang dikasihinya seperti seorang ayah kepada anak yang disayangi.

\section{Nilai Kepribadian Baik}

Nilai kepribadian yang baik adalah nilai keseluruhan sikap, perasaan, ekspresi, dan emosi diri. Sikap tersebut dapat terwujud apabila seseorang dihadapkan pada situasi tertentu.Hal ini sejalan dengan pendapat Derlega, Winstead dan Jones yang mengartikan kepribadian sebagai sistem yang relatif stabil. Megenai karakteristik individu yang bersifat internal, yang berkonstribusi terhadap pikiran, perasan, dan tingkah lakunya 
konsisten. Untuk itu sebagai peserta didik diharapkan untuk mampu mengontrol diri pada situasi-situasi tertentu.

Nilai kepribadian yang baik pada buku cerita rakyat Nias terdapat pada judul “ LUOMEWONA" berikut penggalannya (hal : 11 paragraf ke dua) “Luomewona putra sirao dan istrinya Buruti Rao menunjukkan sikap rendah hati, sederhana, ramah kepada siapa saja, menghargai sesamanya, dan penuh kepasrahan sejak dimulainya pertandingan. Saat kontraks dengan perilaku kedelapan saudaranya.

Nilai kepribadian yang baik adalah nilai keseluruhan sikap, perasaan, ekspresi, dan emosi diri.Sikap tersebut dapat terwujud apabila seseorang dihadapkan pada situasi tertentu.Untuk itu sebagai peserta didik diharapkan untuk mampu mengontrol diri pada situasi-situasi tertentu.

\section{Nilai Kepedulian Sosial}

Swanson (1991) mendefinisikan nilai keperdulian sebagai salah satu cara untuk memelihara hubungan dengan orang lain, dimana orang lain merasakan komitmen dan tanggung jawab pribadi. Noddings (2002) menyebutkan bahwa ketika kita perduli dengan orang lain maka kita akan merespon positif apa yang dibutuhkan oleh orang lain dan ekpresikan menjadi sebuah tindakan.

Menurut Boyatzis dan McKee (2005), keperdulian merupakan wujud nyata dari empati dan perhatian. Ketika kita bersikap terbuka kepada orang lain, maka kita dapat mengahadapi masa-masa sulit dengan kreatifitas dan ketegaran. Empati mendorong kita untuk menjalin hubungan dengan orang. Empati akan muncul ketika kita memulai rasa ingin tahu kita terhadap orang lain dan pengalaman-pengalaman mereka. Namun bagaimanapun cara terbaik untuk memahami apa itu keperdulian adalah dengan cara bagaimana melihat keperdulian tersebut di praktikan. Adapun komponen daripada defenisi keperdulian, yaitu 1) Pemahaman dan empati kepada perasaan dan pengalaman orang lain , 2) Kesadaran kepada orang lain, 3) Kemampuan untuk berpindah berdasarkan perassan tersebut dengan perhatian dan empati.

Nilai kepedulian sosial pada buku cerita rakyat Nias terdapat pada judul "ONO ZAMAGOWAULU" berikut penggalannya (hal : 25 paragraf pertama)" hasil buruan 
sehari cukup untuk kebutuhan seminggu. Makanan pokok mereka adalah daging. Nasi hanya sebagai “ lauk pauk “. Belum terhitung daging yang mereka bagikan kepada tetangga dan lainnya.Keluarga pemburu itu sangat bahagia dengan pekerjaan dan pendapatan mereka pada zaman itu.Nilai karakter keperdulian sosial adalah sikap dan tindakan yang selalu ingin memberi bantuan pada orang lain dan masyarakat yang membutuhkan. Oleh Karena itu sebagai peserta diharapkan memiliki sikap memiliki toleransi terhadap sesama.

\section{Nilai Kejujuran}

Nilai kejujuran tidak hanya diajarkan didalam keluarga tetapi juga disekolah. Peran sekolah dalam menanamkan nilai kejujuran pada anak sangat penting, dengan selalu memberi contoh atau perilaku jujur yang secara lansung akan menumbuhkan nilai kejujuran yang tinggi dan rasa tanggung jawab yang akan berguna bagi dirinya baik dimasa sekarang maupun yang akan datang (Messi dan Edi, 2017). Dalam rangka penanaman nilai-nilai kejujuran disekolah, ada beberapa peran yang dapat dilakukan oleh guru (Amin, 2017), yaitu: 1) Memberikan pengajaran secara terus menerus tentang nilai kejujuran kepada peserta didik, 2) Memberikan keteladanan yaitu dalam kehidupan didalam masyarakat, terkadang banyak kita temukan orang yang suka menyampaikan kebaikan-kebaikan dan contoh perbuatan yang baik. Artinya, bahwa seorang guru hendak berbuat kejujuran itu dimulai dari sendiri dan menjadi teladan bagi peserta didik, 3) Membiasakan berperilaku, yaitu suatu ungkapan yang patut untuk direnungkan adalah " sesuatu bisa karena biasa ". Hal ini mengidentifikasikan bahwa setiap perilaku individu dalam kehidupan sehari-hari karena suatu kebiasaan. Begitu pula tentang kejujuran.

Nilai kejujuran pada buku cerita rakyat Nias terdapat pada judul "ONO ZAMAGOWAULU “ berikut penggalannya (hal : 32 paragraf ke dua) " Sanuhe sebagai yang tertua mengatakan," siapa diantara kita yang telah melanggar pesan ayah ? ayo !mengaku!" sambil memperhatikan satu per satu adik-adiknya. Salah seorang diantara mereka sejak tadi diam seribu Bahasa, menunduk, wajah pucat, diliputi rasa malu, dan takut dengan terbata-bata mengatakan," aku mohon maaf!" setelah mendengar pengakuan itu dengan nada emosi, sidaofa mendekati dan hendak memukul adiknya.Dengan demikian, nilai karakter kejujuran merupakan sikap perilaku 
yang menjadikan dirinya sebagai orang yang selalu daapt di percayai dalam perkataan, tindakan dan pekerjaan.

\section{Nilai Kerja Keras}

Penanaman nilai kerja keras pada karakter masing-masing individu sangat penting guna memperbaiki kehidupan bangsa Indonesia yang jauh dari kata negara yang makmur.Kerja keras bukan berarti bekerja sampai tuntas lalu berhenti, istilah yang dimaksud adalah mengarah pada visi besar yang harus dicapai untuk kebaikan manusia dan lingkungannya. Elfindri, dkk. (2011 : 102) menjelaskan bahwa karakter kerja keras adalah sifat seorang yang tidak mudah berputus asa yang disertai kemauan keras dalam berusaha, dalam mencapai tujuanya dan cita-citanya.

Nilai kerja keras pada buku cerita rakyat Nias terdapat pada judul "ONO ZAMAGOWAULU" berikut penggalannya (hal ; 27 paragraf ke dua)" ayah sangat bahagia memiliki putra-putra yang sangat kreatif tidak putus asa. Iraono sanau famataba ( anak-anak yang memiliki wawasan luas ). Kata sama gowaulu dengan penuh kasih sayang.

Hidayatullah (2010 : 29) mengemukakan kerja keras sebagai kemampuan mencurahkan dan mengerahkan seluruh usaha dan kesungguhan, potensi yang dimiliki sampai akhir masa suatu urusan hingga tujuan tercapai adapun indikator pendidikan karakter kerja keras adalah bekerja ikhlas dan sungguh-sungguh, bekerja melebihi target dan produktif. Nilai karakter kerja keras merupakan sikap pantang putus asa atau tidak mudah menyerah daalm menggapai suatu tujuan yang ingin dicapai.Dengan demikian seorang peserta didik di harapkan memiliki nilai karakter demikian dalam menggapai cita-cita.

\section{Cerita Rakyat Nias Berpotensi Sebagai Pembelajaran Sastra di SMA.}

Salah satu tipe teks yang dipelajari berdasarkan silabus atau pembelajaran sastra di SMA ialah narasi dengan menceriterakan kisah atau nasehat yang terdapat dalam teks cerita rakyat. Materi cerita rakyat termasuk pembelajaran sastra di SMA. Cerita rakyat Nias sangat berpotensi sebagai pembelajaran di SMA mengingat nilai-nilai yang terkandung di dalamnya. Berdasarkan cerita rakyat Molo Manaho ada nilai-nilai religius 
yang terdapat di dalamnya. Nilai religius dapat menjadi sumber karakter siswa di SMA yakni siswa-siswa diajarkan untuk takut akan Tuhan dan mendengarkan didikan orangtua. Selanjutnya, cerita Rakyat Luo Wemonamemuat pembelajaran sastra yang menjadi sumber bentukan karakter siswa-siswi ialah kerendahan hati, kesederhanaan, keramahan. Kemudian, Cerita rakyat Ono Zamagowaulu nilai pembelajaran sastra mencerminkan karakter peduli sosial, kejujuran dan kerja keras. Nilai-nilai ini sangat berharga yang kemudian agar diterapkan oleh siswa dalam hidupnya sehingga menjadi manusia-manusia yang memiliki peradaban.

Cerita rakyat Nias yang mengandung nilai-nilai pendidikan karakter di atas dapat berpotensi kuat sebagai pembelajaran sastra di SMA. Hal ini juga membantu siswa-siswi mempelajari jenis-jenis sastra yang terdapat di setiap suku di Indonesia. Sebab, pembelajaran sastra memiliki tiga aspek yang menjadi tujuan pengajarannya, yaitu kognitif, afektif, dan psikomotor. Ketiganya memang berbeda, namun saling berkaitan dan saling mengisi. Adapun tujuan penyajian sastra dalam dunia pendidikan adalah untuk memperoleh pengalaman dan pengetahuan tentang sastra. Karya sastra seperti cerita rakyat Nias di atas dapat dijadikan sebagai materi memiliki nilai-nilai yang dapat mengembangkan siswa seutuhnya. Selain itu, proses ini diusahakan dapat memungkinkan siswa memperoleh nilai-nilai tersebut dan menerapkannya dalam kehidupan.

Selain itu, Cerita rakyat Nias di atas berpotensi kuat sebagai pembelajaran sastra di SMA karena sifat sastra atau cerita rakyat Nias itu seperti vitamin batin, kerja otak kanan yang membuat halus sikap hidup insani manusia, yang jika benar-benar dimatangkan, akan mampu menumbuhkan sikap yang lebih santun dan beradab bagi hidup siswa-siswi SMA. Nilai-nilai sastra dapat membuat siswa akan semakin mengerti tentang hakikat dan nilai-nilai kemanusiaan. Jiwa kemanusiaan semakin tebal, maka jiwa-jiwa kekerasan yang ada dalam diri manusia termasuk juga siswaakan tenggelam dengan sendirinya. Dengan kata lain, jiwa kekerasan dengan sendirinya akan terhapus dalam diri siswa karena telah mendapatkan nilai-nilai manusia yang terdapat dalam pembelajaran sastra seperi cerita rakyat Nias di atas.

Berdasarkan nilai-nilai sastra itulah, maka sastra bukan lagi permainan kata-kata yang dibolak-balik, diakrobatkan, diliuk-liukan di udara imajinasi agar terkesan bagus, 
indah, dan bersahaja bagi siapa saja yang membacanya. Ternyata sastra mampu menduduki posisi sebagai terapi alternatif atau sumber pembentukan karakter yang berdaya saing. Oleh sebab itu penting bagi sekolah-sekolah untuk melatih daya imajinasi siswanya untuk mencintai dan mempelajari sastra sebagai sumber nilai-nilai dan pembentukan karakter mereka. Bukan hanya itu, pembelajaran sastra diharapkan mampu mampu melahirkan para budayawan dan sastrawan terkenal sebagai pengganti "pendekar" sastra yang nantinya tidak produktif lagi karena ditelan oleh usia.

\section{SIMPULAN DAN SARAN}

Hasil penelitian menunjukkan bahwa nilai-nilai pendidikan karakter yang terdapat dalam cerita rakyat Nias ialah nilai religius, kepribadian baik, kepedulian sosial, kejujuran dan kerja keras. Berdasarkan nilai-nilai pendidikan karakter ini maka cerita rakyat Nias berpotensi kuat untuk dijadikan sebagai pembelajaran sastra di SMA karena cerita rakyat nias memiliki dimensi kognitif, afektif, dan psikomotor. Kemudian, cerita rakyat Nias mampu menumbuhkan sikap yang lebih santun dan beradab bagi hidup siswa-siswi SMA dan juga sumber pembentukan karakter yang berdaya saing.Oleh karena itu agar sastra-sastra lokal dijadikan sebagai materi pembelajaran sastra di SMA demi pembentukan peradaban siswa-siswi sebagai manusia sejati.

\section{DAFTAR PUSTAKA}

Amin. (2017). Pendidikan Karakter Anak Bangsa. Jakarta : Baduose Media.

Arikunto. (2009). Prosedur Penelitian, Suatu Pendekatan Praktek. Jakarta: Rineka Cipta.

Agung. (2011). Character Education Integration in Social Studies Learning International Journal of History Education, Th. XII, No.2, Dec., hlm. 392-403.

Boyatzis, McKee. (2005). Definisi kepedulian. Bandung: Lentera Cahaya

Echols John M. dan Shadily, Hasan. (2015). Kamus Inggris Indonesia. Jakarta : Gramedia.

Elfindri, H. L., dkk. (2012). Pendidikan Karakter : Karakter, Metode dan Aplikasi untuk Pendidik dan Profesional. Jakarta : Baduose Media.

Fraenkel, Wallen. (2007). How to Design and Evaluate Research in Education. New York: Mc Graw. 
Jamaluddin, Dindin. (2013). Paradigma Pendidikan Anak Dalam Islam. Bandung : Pustaka Setia.

Kesuma, dkk.( 2011). Pendidikan Karakter : Kajian Teori dan Praktik di Sekolah. Bandung: PT. Remaja Rosdakarya.

Messi, dan Edi. (2017). Menanamkan Nilai-nilai Kejujuran di Dalam Kegiatan Madrasah Berasrama (Boarding School). Jurnal Manajemen, kepemimpinan, dan Supervisi Pendidikan. 1(1), hal. 278-290.

Muslich, Masnur. (2011). Pendidikan Karakter. Jakarta : Bumi Aksara.

Peraturan Pemerintah RI No. 57 Tahun 2014 tentang Pengembangan, Pembinaan, dan Perlindungan Bahasa dan Sastra, serta Peningkatan Fungsi Bahasa Indonesia.

Sulastri, Septiana. dan Alimin, Al Ashadi. (2010). Nilai Pendidikan Karakter Kerja Keras 